\title{
SCARF1 Gene
}

National Cancer Institute

\section{Source}

National Cancer Institute. SCARF1 Gene. NCI Thesaurus. Code C106361.

This gene plays a role in cholesterol metabolism. 